\title{
IDENTIFIKASI GEJALA STRES PADA GURU TINGKAT SEKOLAH DASAR DI SEKOLAH LENTERA HARAPAN TANGERANG
}

\author{
Suparman \\ Universitas Pelita Harapan, Tangerang \\ suparman.tc@uph.edu
}

\begin{abstract}
Abstrak
Masalah utama dalam penelitian ini adalah rendahnya kesadaran guru terhadap gejala stres dalam dirinya. Padahal stres merupakan sesuatu yang tidak terhindarkan dalam kehidupan masyarakat modern. Stres merupakan suatu kondisi ketegangan yang memiliki pengaruh langsung pada emosi, proses berpikir dan kondisi fisik seseorang. Tujuan dari penelitian ini adalah menemukan atau mengidentifikasi gejala stres pada guru sehingga menumbuhkan self awareness. Penelitian ini menggunakan metode deskriptif kuantitatif untuk menjelaskan fenomena-fenomena yang ada dengan angka-angka sehingga karakteristik individu atau sekelompok individu dapat disingkapkan. Di dunia pendidikan, pekerjaan sebagai guru memiliki potensi level stres yang cukup signifikan. Stres pada guru dapat dipicu oleh adanya berbagai faktor antara lain tekanan terhadap hasil akademik siswa, relasi dengan rekan kerja, relasi dengan orang tua, gaji yang terbatas ataupun masa pensiun yang kurang terjamin. Gejala stres itu nampak dalam keluhan fisik, gangguan psikis ataupun perilaku guru. Hal ini menimbulkan efek dalam kinerja guru sehingga guru-guru perlu dicarikan solusi yang bisa menolong mereka.
\end{abstract}

Kata kunci: guru, gejala stres, self awareness, kinerja guru.

\begin{abstract}
The main problem in this study is the low awareness of teachers towards the symptoms of stress in themselves. Whereas, stress is an inevitable in the life of modern society. Stress is a condition of tension that has a direct influence on the emotions, thinking process and physical condition of a person. The purpose of this study is to find or identify symptoms of stress in teachers so to grow self-awareness. This study uses quantitative descriptive method to explain the phenomena that exist with the numbers so the characteristics of individuals or groups of individuals can be revealed. In the world of education, work as a teacher has a potential level of stress is quite significant. Stress on teachers can be triggered by the existence of various factors such as pressure on student academic results, relationships with colleagues, relationships with parents, limited salaries or pensions are less secure. The symptoms of stress appear in physical complaints, psychological disorders or teacher behavior. This has an effect on teacher performance therefore teachers need to find solutions that can help them.
\end{abstract}

Keywords: teacher, symptoms of stress, self awareness, teacher performance.

\section{Pendahuluan}

Pekerjaan sering kali menjadi sumber stres dalam diri seseorang. Berdasarkan riset yang dilakukan platform komunitas online sejak Agustus 2015 hingga Januari 2017, yang diikuti oleh 86.000 responden di seluruh Indonesia dalam berbagai jenis pekerjaan, ditemukan beberapa kategori pekerjaan dengan tingkat stres yang tinggi. Mereka diminta untuk menilai kehidupan work-life balance selama ini dari skala satu hingga lima. Work-life balance ini berhubungan dengan kemampuan karyawan dalam menghadapi tekanan pekerjaan tanpa mengabaikan berbagai aspek kehidupan pribadi mereka. Besarnya tanggung jawab dan beban yang dirasakan oleh karyawan berbanding terbalik dengan tingkat work-life balance mereka. Semakin besar tekanan dan beban pekerjaan, semakin tinggi pula tingkat stres karyawan, dan akan semakin rendah tingkat work-life balance mereka. Berdasarkan riset itu, rata-rata tingkat stres karyawan Indonesia adalah 3.0. Dari hasil survei juga terungkap fakta menarik yang cukup mengejutkan. Tak disangka jika public speaker, pengasuh anak, dan petugas kesehatan gigi punya level stres paling tinggi. Setelah itu disusul profesi sebagai guru, petugas logistic dan transportasi serta telemarketing (Anjani, 2017).

Pekerjaan sebagai guru memiliki tingkat stres yang cukup signifikan karena pekerjaan guru berhadapan dengan banyaknya tuntutan, interaksi dalam pekerjaan, dan jaminan kesejahteraan yang 
belum merata. Guru berhadapan dengan tuntutan kurikulum ataupun kebijakan sekolah yang kadang sulit dipenuhi. Misalnya adanya tuntutan atau target hasil belajar yang tinggi sementara kemampuan siswa minim, sehingga guru harus bekerja keras dalam proses belajar mengajar untuk meningkatkan kemampuan siswa. Selain itu dalam interaksinya dengan rekan kerja, siswa maupun orang tua siswa juga berpotensi menimbulkan konflik yang tidak diharapkan. Sedangkan berkaitan dengan jaminan, ada guru-guru honorer yang cenderung mendapatkan upah terbatas ataupun guru-guru sekolah swasta yang mendapatkan gaji minim. Hal itu menimbulkan tekanan tersendiri bagi profesi sebagai guru.

\section{Kajian Literatur}

\section{Stres pada Guru}

Stres merupakan sesuatu yang tidak terhindarkan dalam kehidupan masyarakat modern. Dengan berkembangnya teknologi dan cepatnya ritme hidup modern menambah tekanan dalam kehidupan manusia. Setiap orang berpacu dengan waktu dan berusaha menyelesaikan tugas dan tanggung jawabnya hari demi hari. Hampir setiap segi kehidupan menimbulkan tekanan dan memiliki level stres tersendiri.

Stres merupakan suatu kondisi ketegangan yang memiliki pengaruh langsung pada emosi, proses berpikir dan kondisi fisik seseorang. Hal ini seperti yang diungkapkan Manduku dkk. (2016) demikian, "Stress is a condition of strain that has a direct bearing on emotions, thought process and physical conditions of a person." Stres sering kali dihubungkan dengan adanya tuntutan. Robbins mengatakan, "Stress is more often associated with constraints and demands, with constraint prevents one from doing what he/she desire" (Robbins, 2002).

Manduku, dkk (2016) menjelaskan bahwa lingkungan pekerjaan memberikan efek yang signifikan terhadap level stres seseorang. Apalagi sebagai seorang guru, cenderung diperhadapkan dengan situasi yang penuh dengan tekanan. Voughan (2013, 12) dalam penelitian yang dilakukan oleh Kyriacou (1998) ditemukan bahwa 20\%-25\% guru sering diperhadapkan dengan stres yang besar. Ada beberapa pemicu stres pada guru, misalnya berkaitan dengan hasil akademik peserta didik, relasi dengan rekan kerja, suasana belajar di kelas, dan relasi dengan orang tua murid. Vaughan $(2012,12)$ lebih lanjut menyatakan, "Stress among teachers is related to absenteeism, turnover, and early retirement, which negatively affect the climate of the school and lead to poor student outcomes, both academically and behaviorally." Hal ini menimbulkan efek dalam kinerja guru sehingga perlu diberikan pelatihan stres management untuk meminimalkan efek stres dan meningkatkan kinerja guru.

Beberapa riset menunjukkan bahwa pekerjaan sebagai guru, pekerja sosial, ahli bahasa merupakan pekerjaan dengan tingkat stres yang tinggi dan pemicu stres dikaitkan dengan lingkungan kerja mereka. Selain karakteristik pribadi, tekanan yang cukup berat juga dirasakan oleh guru dalam kaitan dengan kodisi pekerjaan yang buruk kurang sumber daya sehingga beban guru berlebihan dan berkaitan dengan perilaku siswa. Hal ini seperti yang dikatakan Manduku, dkk. (2016) yang mengutip Gugliemi dan Tatrow:

"Recent research has shown that teachers, along with servicemen, social workers, and linguists, are the most affected by rising stress in their respective work environments. One out of three teachers report teaching as being very or extremely stressful, causing the teaching profession to have the highest annual turnover rate. Teacher stress is caused by environmental factors as well as individual characteristics. Major environmental factors include poor working conditions, scarcity of resources, heavy workloads, and student behavior. Individual characteristics can include gender, age, personality, and the ability to cope (Guglielmi \& Tatrow, 1998).

Selanjutnya Blaze (1986) membagi dua kelompok pemicu stres. Kelompok pertama adalah pemicu stres yang berkaitan dengan interaksi dengan siswa. Dalam kelompok ini terdapat faktor tuntutan siswa, sikap siswa yang apatis, jumlah siswa dalam kelas yang begitu besar tidak sebanding dengan jumlah guru, sikap siswa seperti disiplin siswa, jumlah kehadiran siswa (siswa membolos), pekerjaan persiapan mengajar dan koreksi, rekan kerja yang tidak bertanggung jawab, orang tua yang kurang mendukung, urusan administrasi yang rumit dan kepemimpinan kepala sekolah yang lemah. Kelompok pemicu stres yang kedua berkaitan dengan gaji yang rendah, keletihan secara emosi, frustrasi, merasa tidak berdaya, stagnasi, kebosanan dan kehilangan motivasi atau sikap antusias (Manduku, dkk, 2016). Hal ini juga didukung berbagai penelitian yang dikutip Manduku, dkk. (2016):

"Stress among teachers can also be grouped into three categories: role demands, instructional problems, and interpersonal relationships (Sutton, 1984). Role related stress is said to be the difference between teachers' role expectations and their actual experiences within that role (Pettegrew \& Wolf, 1982). Role demand stressors include ambiguity, overload, conflict (Sutton, 1984), preparedness, and nonparticipation (Pettegrew \& Wolf, 1982). Organizational characteristics such as policies, structure, and processes can also be categorized as role demand stressors (Bacharach, Bauer, \& Conley, 1986). Instructional problems or task stress identifies problems associated with a variety of specific tasks that teachers must perform in their teaching role (Pettegrew \& Wolf, 1982). Instructional problems can include 
difficulties with student discipline, competence, inappropriate procedures for student placement, instruction, inadequate standardized tests, grading systems (Sutton, 1984), notification of unsatisfactory work performance, being physically threatened by students (Pettegrew \& Wolf, 1982) and sparse or dangerous working conditions (Bacharach, Bauer, \& Conley, 1986). Interpersonal relationships refer to relationships teachers have with fellow professionals or community members within the educational environment. Network interaction and supervision may also fall into this category (Bacharach, Bauer, \& Conley, 1986). The most common stressors in this group are conflict with other staff members, and a lack of social support from supervisors and coworkers (Sutton, 1984)."

Dengan demikian dapat diidentifikasi beberapa pemicu stres pada guru.

\section{Mengenali Gejala Dampak Stres}

Ketika seseorang stres, tubuh akan memberikan respon yang akhirnya memengaruhi kondisi psikis, fisik, dan akhirnya memengaruhi perilaku seseorang. Lumban Gaol (2016) mengutip Jovanovic, Lazaridis dan Stefanovic (2006) yang mengklasifikasikan gejala atau tanda yang di alami apabila individu mengalami stres sebagai berikut:

- Pertama adalah gejala stres berkaitan dengan fisik, yaitu: sakit kepala, masalah pencernaan, kurang tidur, gatal-gatal, nyeri ulu hati, keringat malam, keinginan seksual yang berkurang, ketidak-teraturan menstruasi, nyeri punggung kronis, otot tegang, kehilangan nafsu makan, berat badan.

- Kedua adalah gejala stres yang berkaitan dengan emosional atau mental, yaitu: peningkatan kemarahan, frustrasi, depresi, kemurungan, kecemasan, masalah dengan memori, kelelahan, dan peningkatan penggunaan nikotin, alkohol, dan obatobatan.

- Ketiga adalah gejala stres berkaitan dengan kerja, yaitu: peningkatan absensi, kecelakaan pada pekerjaan, keluhan dari rekan kerja, penurunan kerja produktivitas, kesulitan dalam memahami peraturan kantor, absensi dari pekerjaan, mengambil waktu rehat terlalu lama, waktu pribadi yang berlebihan pada telepon atau internet.

Selain itu dalam penelitian Blasé (1986) yang meneliti gejala stres di kalangan guru ditemukan bahwa ada kalanya stres yang dialami guru menyebabkan timbulnya perasaan negatif yang sebenarnya tidak diinginkan seperti kemarahan. Manduku (2016) mengungkapkan:

Some teachers may also have an emotional response to unwanted stress. The most common feelings of emotion that occur are anger, depression, anxiety, and self-blame (Blasé, 1986). Teachers experience anger more than any other feeling as a consequence of work stress and is often expressed with strong negative feelings directed towards others.

Selain itu stres juga membuat guru merasa cemas yang termanifestasi dalam sikap antisipasif, kurang sabar dan cenderung kritikal terhadap siswa. Hal ini seperti yang diungkapkan Manduku (2016):

Feelings of anxiety are mostly anticipatory and often occur when teachers expect negative consequences to occur (Blasé, 1986). As feelings of anxiety continue, teachers become less tolerant, patient, caring, and involved (Blasé, 1986), and may even become unrealistically biased in their judgments and assessments of learners, which can result in negative outcomes for students (Abidin \& Robinson, 2002).

Menurut Blasé jika perasaan itu terus berlanjut akan menyebabkan terganggunya proses belajar mengajar. Relasi guru dan siswa akan mengalami konflik sehingga siswa enggan terlibat dalam interaksi belajar. Guru cenderung mengalami perubahan suasana hati ketika meresponi perilaku siswa. Hal ini akhirnya membuat guru cenderung menyalahkan diri sendiri dan cenderung merasa putus asa dengan situasi yang dihadapinya. Lebih tepatnya Manduku (2016) mengungkapkan:

Self-blame results in teachers expressing anger towards self, feelings of guilt, and feelings of self-pity (Blasé, 1986). Over time, self-blame can remove teachers emotionally and socially from their students. A loss of enthusiasm may also occur causing teachers to lessen their attempts of humor, elaboration of subject matter, and creative involvement (Blasé, 1986).

Selain itu Manduku (2016) juga mendaftarkan berbagai gejala fisik yang dialami guru dari beberapa penelitian dengan mengungkapkan:

Stress may also elicit a physical or physiological response from teachers. Some physical symptoms of stress include fatigue, tiredness, overworked, burn out, headaches, stomach aches, chest pains, sleepiness (Blasé, 1982), trembling hands, shortness of breath, dizziness, restlessness, cold sweats, ill health, confused thoughts or difficulty concentrating, loss of memory, loss of appetite, trouble falling asleep, and the ability to hold productive conversations with colleagues (Bacharach, Bauer, \& Conley, 1986). Some physiological symptoms of stress include an increase in blood pressure, heart rate and or cortisol (Guglielmi \& Tatrow, 1998), irregular heartbeat, and nervousness (Bacharach, Bauer, \& Conley, 1986).

Dengan demikian stres termanifestasi dalam gejala psikis, fisik, maupun gejala perilaku yang bisa diamati. 


\section{Metodologi Penelitian}

Penelitian ini menggunakan metode deskriptif kuantitatif. Syamsudin (2011) menyebut penelitian ini sebagai penelitian yang bertujuan menjelaskan fenomena yang ada dengan menggunakan angka-angka untuk mencandarkan karakteristik individu atau kelompok. Penelitian ini menilai sifat dari kondisi-kondisi yang tampak. Tujuan penelitian dengan metode ini terbatas hanya untuk menggambarkan karakteristik sesuatu sebagaimana adanya. Sampel dalam penelitian ini adalah 36 guru di Sekolah Dasar Lentera Harapan Tangerang. Pengisian survey dilakukan pada saat acara personal development guru yang diadakan di sekolah tersebut. Responden menjawab setiap pernyataan dengan 5 pilihan skala yang menunjukkan sampai seberapa jauh pernyataan tersebut sesuai dengan dirinya (tidak pernah, pernah, kadang-kadang, sering dan hampir selalu).

\section{Hasil dan Pembahasan}

Berdasarkan hasil survey yang dilakukan, ditemukan data yang dapat dilihat pada Tabel 1 sebagai berikut:

Tabel 1. pemicu stres pada guru di Sekolah Lentera Harapan Tangerang

\begin{tabular}{|r|l|r|r|r|r|r|}
\hline No & \multicolumn{1}{|c|}{ Pemicu } & $\begin{array}{r}\text { Tidak } \\
\text { pernah }\end{array}$ & Pernah & $\begin{array}{c}\text { Kadang- } \\
\text { kadang }\end{array}$ & Sering & $\begin{array}{c}\text { Hampir } \\
\text { selalu }\end{array}$ \\
\hline 1 & Pengelolaan kelas/suasana belajar & $5,55 \%$ & $38,89 \%$ & $33,33 \%$ & $16,67 \%$ & $5,55 \%$ \\
\hline 2 & Tuntutan kurikulum & $5,55 \%$ & $25 \%$ & $36,11 \%$ & $25 \%$ & $5,55 \%$ \\
\hline 3 & Relasi dengan rekan kerja & $2,78 \%$ & $27.78 \%$ & $47,22 \%$ & $22,22 \%$ & 0 \\
\hline 4 & Perilaku siswa di dalam kelas & $8,33 \%$ & $33,33 \%$ & $36,11 \%$ & $16,67 \%$ & $2,78 \%$ \\
\hline 5 & Relasi dengan orang tua murid & $25 \%$ & $44,44 \%$ & $22,22 \%$ & $8,33 \%$ & 0 \\
\hline 6 & Kesejahteraan guru (gaji) & $11,11 \%$ & $30,55 \%$ & $27,78 \%$ & $22,22 \%$ & $8,33 \%$ \\
\hline 7 & Persiapan mengajar (RPP) & $13,89 \%$ & $41,67 \%$ & $25 \%$ & $11,11 \%$ & $8,33 \%$ \\
\hline 8 & Kekuatiran akan masa depan (karir) & $2,78 \%$ & $27,78 \%$ & $27,78 \%$ & $25 \%$ & $16,67 \%$ \\
\hline 9 & Koreksi tugas/ujian siswa & $19,44 \%$ & $33,33 \%$ & $25 \%$ & $11,11 \%$ & $11,11 \%$ \\
\hline 10 & Kebijakan/aturan sekolah & $13,89 \%$ & $33,33 \%$ & $30,55 \%$ & $16,67 \%$ & $5,55 \%$ \\
\hline
\end{tabular}

Tabel tersebut menunjukkan bahwa pemicu stres pada guru di Sekolah Lentera Harapan Tangerang berkaitan erat dengan kekuatiran akan masa depan. Ada $41.67 \%$ responden menjawab sering dan hampir selalu mengalami kekuatiran akan masa depan. Selanjutnya ada $30,55 \%$ responden menjawab sering dan hampir selalu yang menghubungkan pemicu stres dengan kesejahteraan guru dan tuntutan kurikulum. Sedangkan 22,22\% responden menjawab sering dan selalu untuk stres yang berkaitan dengan pengelolaan kelas, relasi dengan rekan kerja, koreksi ujian siswa, kebijakan/aturan sekolah. Hal ini mengindikasikan bahwa pemicu stres guru berkaitan dengan masalah gaji dan tuntutan pekerjaan yang cukup berat.
Dengan demikian banyak sekali tekanan yang dialami oleh seorang guru. Jika tekanan ini tidak dikelola akan menimbulkan masalah emosional yang semakin serius sehingga menggangu kinerja guru bahkan ada kemungkinan guru tersebut memutuskan untuk mengundurkan diri.

\section{Mengenali Gejala Stres}

Gejala stres dapat ditemukan dalam semua aspek hidup manusia, baik secara kognitif, emosi, perilaku ataupun berpengaruh pada kondisi fisik individu. Dari hasil survey, ditemukan data yang dapat dilihat pada Tabel 2 sebagai berikut:

Tabel 2. Gejala stres dalam aspek hidup manusia

\begin{tabular}{|l|l|l|l|l|l|l|}
\hline No & Gejala Psikis & Tidak pernah & Pernah & Kadang-kadang & Sering & Hampir selalu \\
\hline 1 & Masalah memori dan konsentrasi & $2,78 \%$ & $36,11 \%$ & $33,33 \%$ & $25 \%$ & $2,78 \%$ \\
\hline 2 & Merasa cemas, kuatir berlebih & $11,11 \%$ & $33,33 \%$ & $38,89 \%$ & $13,89 \%$ & $2,78 \%$ \\
\hline 3 & Mudah marah/tidak sabaran & $5,55 \%$ & $41,67 \%$ & $25 \%$ & $22,22 \%$ & $5,55 \%$ \\
\hline 4 & Merasa putus asa & $16,67 \%$ & $22,22 \%$ & $16,67 \%$ & $13,89 \%$ & $2,78 \%$ \\
\hline 5 & Merasa gagal & $13,89 \%$ & $47,22 \%$ & $22,22 \%$ & $16,67 \%$ & 0 \\
\hline 6 & Rendah diri/merasa tidak mampu & $13,89 \%$ & $41,67 \%$ & $27,78 \%$ & $16,67 \%$ & 0 \\
\hline 7 & Mudah menyalahkan orang lain & $16,67 \%$ & $44,44 \%$ & $27.78 \%$ & $8,33 \%$ & $2,78 \%$ \\
\hline 8 & Tegang & $2,78 \%$ & $36,11 \%$ & $44,44 \%$ & $11,11 \%$ & $5,55 \%$ \\
\hline 9 & Sensitif terhadap kritik & $2,78 \%$ & $36,11 \%$ & $44,44 \%$ & $11,11 \%$ & $5,55 \%$ \\
\hline 10 & Perubahan mood & $5,55 \%$ & $33,33 \%$ & $41,67 \%$ & $11,11 \%$ & $8,33 \%$ \\
\hline
\end{tabular}


Dari tabel 2 ditemukan ada 27,78\% responden menjawab sering dan hampir selalu yang mengakui bahwa gejala stres tampak dalam masalah memori dan konsentrasi. Bukan hanya itu saja mereka juga mengaku menjadi mudah marah/tidak sabaran. Ada 19,44\% rensponden menjawab bahwa mereka sering atau bahkan hampir selalu mengalami perubahan mood. Dengan demikian gejala stres yang memengaruhi psikis juga menjadi masalah serius yang harus dihadapi oleh guru.

Selain memengaruhi kondisi psikis guru, stres juga menimbulkan gejala fisik. Dari survey yang dilakukan ditemukan data sebagai berikut:

Tabel 3. Pengaruh stres terhadap gejala fisik

\begin{tabular}{|c|l|r|r|r|r|r|}
\hline No & \multicolumn{1}{|c|}{ Gejala Fisik } & $\begin{array}{c}\text { Tidak } \\
\text { pernah }\end{array}$ & Pernah & $\begin{array}{c}\text { Kadang- } \\
\text { kadang }\end{array}$ & Sering & $\begin{array}{c}\text { Hampir } \\
\text { selalu }\end{array}$ \\
\hline 1 & Sakit kepala & $8,33 \%$ & $41,67 \%$ & $19,44 \%$ & $27,78 \%$ & $2,78 \%$ \\
\hline 2 & Nyeri otot/badan terasa kaku & $19,44 \%$ & $33,33 \%$ & $27,78 \%$ & $16,67 \%$ & $2,78 \%$ \\
\hline 3 & Kelelahan tanpa sebab yang jelas & $11,11 \%$ & $30,55 \%$ & $33,33 \%$ & $19,44 \%$ & $5,55 \%$ \\
\hline 4 & Sesak nafas & & $36,11 \%$ & $5,55 \%$ & $2,78 \%$ & 0 \\
\hline 5 & Sakit perut/diare & $38,89 \%$ & $38,89 \%$ & $19,44 \%$ & $2,78 \%$ & 0 \\
\hline 6 & Sering flu (daya tahan tubuh lemah) & $33,33 \%$ & $47,22 \%$ & $5,55 \%$ & $8,33 \%$ & $5,55 \%$ \\
\hline 7 & Asam lambung tinggi & $50 \%$ & $13,89 \%$ & $27,78 \%$ & $5,55 \%$ & $2,78 \%$ \\
\hline 8 & Denyut jantung cepat & $30,55 \%$ & $38,89 \%$ & $22,22 \%$ & $8,33 \%$ & 0 \\
\hline 9 & Gangguan tidur & $25 \%$ & $27,78 \%$ & $27,78 \%$ & $13,89 \%$ & $5,55 \%$ \\
\hline 10 & Berat badan meningkat/turun & $25 \%$ & $36,11 \%$ & $27,78 \%$ & $8,33 \%$ & $2,78 \%$ \\
\hline
\end{tabular}

Dari tabel di atas ditemukan bahwa ada $30,56 \%$ responden menjawab sering dan hampir selalu mengalami sakit kepala. Ada 24,99\% responden menjawab sering dan hampir selalu mengalami kelelahan tanpa sebab yang jelas dan ada $19,44 \%$ responden menjawab sering dan hampir selalu mengalami gangguan tidur. Dengan demikian gejala stres yang memengaruhi fisik juga menjadi masalah serius yang harus dihadapi oleh guru.

Gejala berikutnya yang sering berkaitan dengan stres adalah adanya gejala perilaku. Dari survey yang dilakukan ditemukan data sebagai berikut:

Tabel 4. Gejala perilaku stres

\begin{tabular}{|c|l|l|l|l|l|l|}
\hline No & \multicolumn{1}{|c|}{ Gejala Perilaku } & \multicolumn{1}{|c|}{$\begin{array}{c}\text { Tidak } \\
\text { pernah }\end{array}$} & Pernah & $\begin{array}{c}\text { Kadang- } \\
\text { kadang }\end{array}$ & Sering & \multicolumn{1}{|c|}{$\begin{array}{c}\text { Hampir } \\
\text { selalu }\end{array}$} \\
\hline 1 & $\begin{array}{l}\text { Makan \& tidur terlalu banyak atau } \\
\text { terlalu sedikit }\end{array}$ & $5,55 \%$ & $36,11 \%$ & $19,44 \%$ & $33,33 \%$ & $5,55 \%$ \\
\hline 2 & $\begin{array}{l}\text { Menunda-nunda atau mengabaikan } \\
\text { tanggung jawab }\end{array}$ & $25 \%$ & $25 \%$ & $33,33 \%$ & $13,89 \%$ & $2,78 \%$ \\
\hline 3 & Manajemen waktu yang buruk & $22,22 \%$ & $30,55 \%$ & $22,22 \%$ & $19,44 \%$ & $5,55 \%$ \\
\hline 4 & Tidak memerhatikan penampilan diri & $25 \%$ & $38,89 \%$ & $30,55 \%$ & $2,78 \%$ & $2,78 \%$ \\
\hline 5 & Menarik diri dari relasi & $19,44 \%$ & $44,44 \%$ & $19,44 \%$ & $8,33 \%$ & $8,33 \%$ \\
\hline 6 & Agresif/ingin mendominasi & $36,11 \%$ & $33,33 \%$ & $25 \%$ & $5,55 \%$ & 0 \\
\hline 7 & Mudah sedih dan menangis & $8,33 \%$ & $38,89 \%$ & $25 \%$ & $25 \%$ & $2,78 \%$ \\
\hline 8 & Kegiatan dilakukan dengan terburu-buru & $11,11 \%$ & $38,89 \%$ & $27,78 \%$ & $16,67 \%$ & $5,55 \%$ \\
\hline 9 & Perilaku bermusuhan & $30,55 \%$ & $44,44 \%$ & $19,44 \%$ & $2,78 \%$ & $2,78 \%$ \\
\hline 10 & Kebersihan pribadi kurang & $52,78 \%$ & $36,11 \%$ & $5,55 \%$ & $2,78 \%$ & 0 \\
\hline
\end{tabular}

Dari tabel tersebut ditemukan ada $38,88 \%$ responden menjawab sering dan hampir selalu mengalami gangguan makan dan tidur. Ada 27,78\% responden yang menjawab sering dan hampir selalu mudah sedih dan menangis pada saat menghadapi stres dan $24,99 \%$ responden yang menjawab sering dan hampir selalu mengalami manajemen waktu yang buruk pada saat stres. Dengan demikian gejala stres yang termanifestasi dalam berbagai perilaku yang merugikan juga menjadi masalah serius yang harus dihadapi oleh guru.

\section{Kesimpulan dan Saran}

Berdasarkan survey di atas, secara umum dapat diambil kesimpulan bahwa guru-guru mengalami tekanan yang termanifestasi dalam keluhan psikis, fisik maupun gejala perilaku yang tampak. Adapun yang menjadi sumber tekanan tersebut berkaitan dengan kekuatiran akan masa depan, masalah kesejahteraan dan adanya tuntutan kurikulum dalam sekolah tertentu. Hal ini tentunya sesuatu yang tidak terhindarkan dalam pekerjaannya sebagai seorang guru. 
Oleh sebab itu perlu dipikirkan suatu solusi untuk membantu para guru mengatasi tekanan di tempat kerja. Ada beberapa usulan solusi yang ditawarkan misalnya pengadaan layanan konseling bagi guru, pengadaan training manajemen stres ataupun grup terapi manajemen stress buat guru. Dari ketiganya yang cukup efektif adalah grup terapi manajemen stres bagi guru. Tujuan grup terapi manajemen stres bagi guru antara lain untuk memberikan suatu wadah bagi terciptanya dukungan emosi dan sosial di antara para guru. Selain itu juga akan diajarkan untuk mengenali gejala-gejala stres serta efeknya bagi pekerjaan sebagai seorang guru. Selanjutnya akan diajarkan berbagai macam teknik untuk mengelola stres yang mencakup aspek emosi, kognitif, perilaku dan aspek fisik. Dengan demikian diharapkan program grup terapi ini bisa menolong para guru untuk mengelola stres yang ada.

\section{Daftar Acuan}

Anjani, Rahmi. "Daftar Profesi di Indonesia dengan Tingkat Stres Paling Tinggi." Available from https://wolipop.detik.com/read/2017/02/28/191 501/3434504/1133/daftar-profesi-di-indonesiadengan-tingkat-stres-paling-tinggi. Akses 28 Maret 2018

Manduku, Joshua. Zipporah Koech and Pascalia Chepkirui. (2016). "Stress Management Strategies and their Effects on Teachers' Commitment in Primary Schools in Sabatia District, Vihiga County, Kenya.” Educational Research Journal Vol. 6 (1):1-12, January (2016).

Vaughan, Debi Kipps. "Supporting Teachers Through Stress Management", Principal Leadership, Januari 2013.

Nasib Tua Lumban Gaol, Teori Stres: Stimulus, Respons, dan Transaksional, Buletin Psikologi 2016, Vol. 24, No. 1, 1 - 11. Available from (https://jurnal.ugm.ac.id/buletinpsikologi). Akses 25 Maret 2018.

Syamsuddin, dkk. (2011). Metode Penelitian Pendidikan Bahasa. Bandung: PT. Remaja Rosdakarya.

\section{Riwayat Penulis}

Suparman, S.Pd., S.Th., M.Th.K. lahir di Malang, 21 April 1969. Penulis merupakan alumni IKIP Negeri Malang tahun 1994, dan menyelesaikan pendidikan S2-nya di STTRI pada tahun 2015 dalam bidang konseling. Pernah menjadi koordinator TK, SD, dan SLTP di SK Aletheia Genteng, Banyuwangi pada tahun 1999 - 2004. Sejak tahun 1990 hingga saat ini aktif sebagai pembicara dalam berbagai seminar pendidikan dan keluarga, juga kegiatan pembinaan anak-anak, remaja, pemuda, pasangan suami-istri di berbagai kota. Pernah menjadi konselor paruh waktu di beberapa sekolah. Sejak
2016 hingga saat ini penulis bekerja sebagai tenaga pengajar (dosen) di Fakultas Ilmu Pendidikan Universitas Pelita Harapan. 